\title{
Oxidative stress and autophagy in cardiac disease, neurological disorders, aging and cancer
}

\author{
Eric E. Essick' and Flora Sam ${ }^{1,2, *}$
}

${ }^{1}$ Whitaker Cardiovascular Institute; ${ }^{2}$ Cardiovascular Section and Evans Department of Medicine; Boston University School of Medicine; Boston, MA USA

Key words: autophagy, reactive oxygen species, oxidative stress, ischemia/reperfusion injury, pathogenesis

\begin{abstract}
Autophagy is a catalytic process of the bulk degradation of long-lived cellular components, ultimately resulting in lysosomal digestion within mature cytoplasmic compartments known as autophagolysosomes. Autophagy serves many functions in the cell, including maintaining cellularhomeostasis, a means of cell survival during stress (e.g., nutrient deprivation or starvation) or conversely as a mechanism for cell death. Increased reactive oxygen species (ROS) production and the resulting oxidative cell stress that occurs in many disease states has been shown to induce autophagy. The following review focuses on the roles that autophagy plays in response to the ROS generated in several diseases.
\end{abstract}

\section{Introduction}

While production of reactive oxygen species (ROS) is a consequence of basal cellular respiration, increased ROS production is associated with several pathological conditions (i.e., hypoxia, ischemia) in many cellular systems. ${ }^{1} \mathrm{ROS}$ can alter gene/ protein expression by acting as second messenger molecules that can influence intercellular signaling cascades, ultimately affecting cell phenotype and function. ${ }^{2}$ Additionally, ROS can directly oxidize cellular components (i.e., lipids, DNA, proteins, mitochondrial components) leading to detrimental effects on the cell and contributing to disease progression. ROS have been ascribed as positive regulators of autophagy, a process of bulk degradation of organelles and proteins, in a multitude of cell systems, which may contribute to the ultimate fate of the cell, be it cell survival or death. ${ }^{3}$ This review highlights the roles of autophagy in response to ROS and increased conditions of oxidative stress and the relationship to several disease states (i.e., cancer, aging, neurological and vascular disorders).

\section{Autophagy}

Autophagy is a tightly regulated and evolutionary conserved process, and includes three main forms: chaperone-mediated autophagy (CMA), microautophagyand macroautophagy. ${ }^{4,5} \mathrm{CMA}$

*Correspondence to: Flora Sam; Email: flora.sam@bmc.org

Submitted: 04/04/10; Revised: 04/18/10; Accepted: 04/19/10

Previously published online:

www.landesbioscience.com/journals/oximed/article/12106 has been described exclusively in mammals and evolutionary data indicates it developed in response to the evolving needs of the species. ${ }^{6}$ CMA requires the complete unfolding of the autophagic materials prior to entry into lysosomes, and allows for individual proteins to be singled out and degraded. ${ }^{7}$ In contrast, both micro and macroautophagy sequester large amounts of cytosolic components for bulk degradation. ${ }^{8}$ Furthermore, microautophagy is characterized by the direct uptake of these cytosolic constituents through an invagination of the lysosomal membrane. 'This review focuses on macroautophagy (hereafter referred to as simply "autophagy"), which is a more common yet more complex mechanism for protein and organelle degradation in lysosomal vacuoles. ${ }^{10}$ During this catabolic process, long-lived organelles and cytoplasmic proteins are initially engulfed into polymembrane vesicles, known as phagophores. The edges of these phagophores expand in a process of vesicle elongation, and fuse to form the mature autophagosome. ${ }^{4,11}$ These autophagosomes subsequently fuse with intercellular lysosomes, forming autophagolysosomes, inside of which the damaged sequestered material is degraded by lysosomal hydrolases. ${ }^{12,13}$

\section{Regulation of Autophagosome Formation}

The formation of the autophagosome in mammalian cells involves autophagy-related proteins (ATG), which are tightly regulated, most notably downstream of mammalian target of rapamycin (mTOR) Ser/Thr kinase. ${ }^{14}$ Autophagosome formation is inhibited when activated mTOR phosphorylates ATG13, preventing this protein from forming a complex with ATG1. This results in the inhibition of ATG1 kinase, which is essential for autophagic induction. ${ }^{4}$ During the autophagic-initiation step, dephosphorylation and inactivation of mTOR allows for the association of ATG13 and ATG1, thereby activating the ATG1 kinase activity and thus initiating autophagy (Fig. 1A). ${ }^{5}$ Isolation membrane elongation involves two highly-conserved ubiquitin-like conjugation complexes in eukaryotes, including the ATG12-ATG5 complex, and the microtubule-associated protein 1 light chain 3 (yeast ATG8 mammalian homologue) phosphatidylethanolamine (LC3-PE). ${ }^{10,15,16}$ Facilitated by ATG7 and ATG10 enzymes, the ATG12-ATG5 conjugate binds ATG16 and this resulting complex is incorporated into the outer membrane of the isolation membrane and is essential for vesicle elongation (Fig. 1B) ${ }^{17}$ In the LC3-PE conjugation system, full length LC3 precursor is subjected to proteolytic 


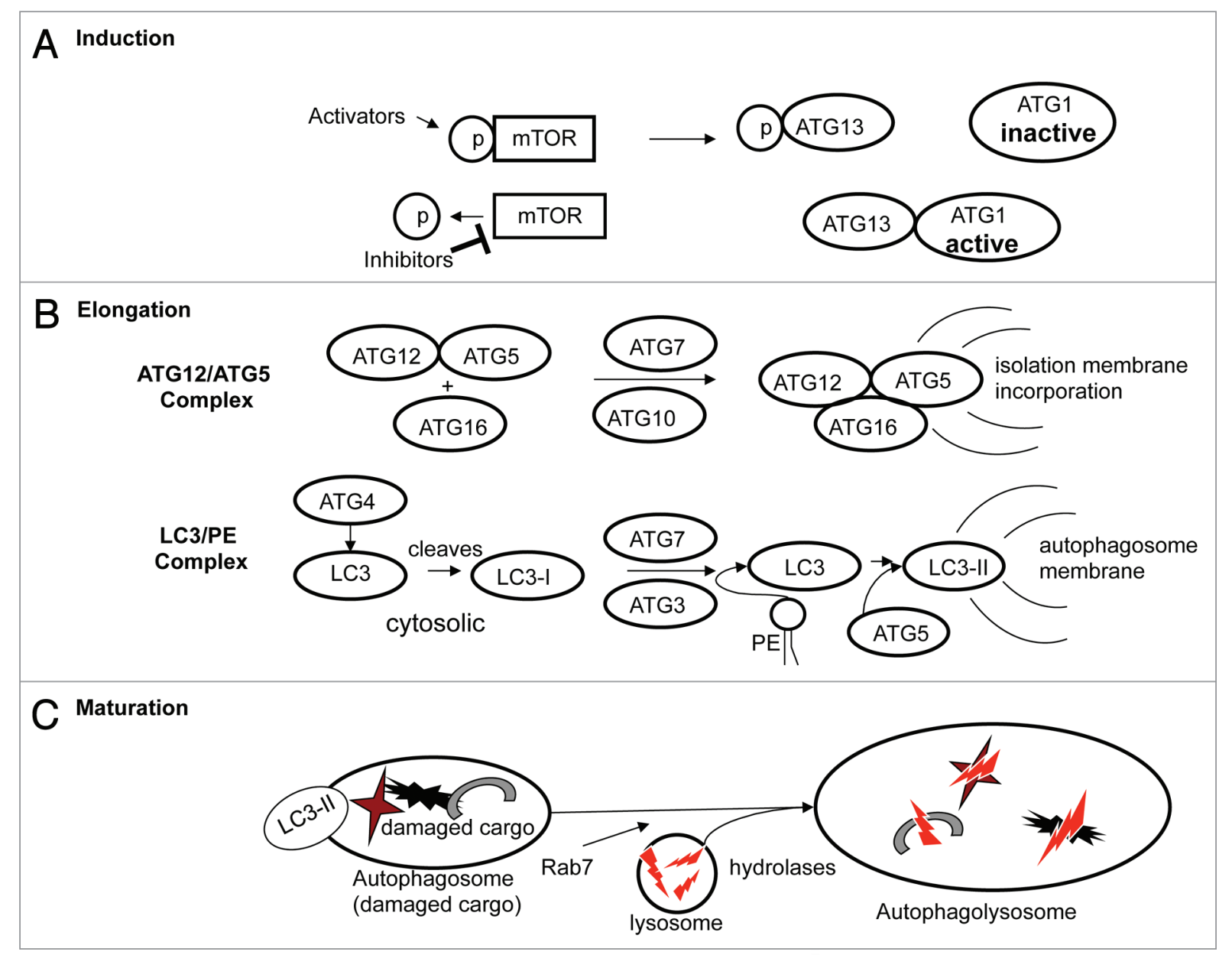

Figure 1. Autophagosome formation. (A) Induction: mTOR inhibition leads to downstream dephosphorylation of ATG13, allowing for its association with ATG1. This ATG13-ATG1 complex activates the kinase activity of ATG1. (B) Elongation of the isolation membrane: ATG12-ATG5, facilitated by both ATG7 and ATG10, binds ATG16 and this resulting complex becomes incorporated into the outer membrane of the isolation membrane. In addition the full-length LC3 precursor is cleaved by ATG4, forming LC3-I, located in the cytosol. ATG7 and ATG3 (ubiquitin-conjugating enzyme-like molecules), aid in LC3-I conjugation to PE, and this resulting complex (referred to as LC3-II), is incorporated into to the autophagosome membrane aided by ATG5. (C) Autophagosome maturation: The mature autophagosomes fuse with cytosolic lysosomes and are mediated by lysosomal receptor proteins (Lamp-1, Lamp-2) and Rab7. The resulting autophagolysosome is where cellular material and components are sequestered and hydrolyzed.

cleavage by the cystein protease ATG4, forming LC3-I. ${ }^{10}$ LC3-I is localized in the cytosol, and through the action of ubiquitin-conjugating enzyme-like molecules ATG7 and ATG3, is conjugated to PE. ${ }^{12}$ LC3-PE (referred to as LC3-II), is then localized to the autophagosome membrane through the assistance of ATG5 (Fig. 1B). ${ }^{18}$ Incidentally, the ratio of the protein expression of membrane associated LC3-II to cytosolic LC3-I (LC3II:I), is indicative of autophagosome formation, and therefore is often used to assess autophagic activity. ${ }^{19}$ Additionally, cellular transfection of green-fluorescent protein(GFP)-LC3 allows for microscopic observation of autophagy by analyzing the amount of cells displaying GFP-LC3 puncta versus those cells displaying a more diffuse fluorescence. ${ }^{20,21}$ Finally, lysosomal receptor proteins (Lamp-1 and Lamp-2) and the Rab GTPase Rab7 mediate the fusion of the mature autophagosomes with cytosolic lysosomes forming the autophagolysosome, and the sequestered components are hydrolyzed (Fig. 1C). ${ }^{22,23}$

\section{Oxidative Stress Induces Autophagy}

Cellular oxidative stress and increased generation of ROS have been reported to serve as important stimuli of autophagy during periods of nutrient deprivation, ischemia/reperfusion, hypoxia, and in response to cell stress. ${ }^{3,24-26}$ The cysteine protease ATG4 functions to cleave all homologues of ATG8 proximal to the C-terminus, priming ATG8 for subsequent conjugation to PE. ${ }^{27}$ Like LC3-PE, lipidated ATG8 will incorporate into the autophagosome membrane, which is necessary for autophagosome maturation. ${ }^{28}$ However, ATG8-PE is also subjected to the proteolytic activity of ATG4, and therefore ATG4 can deconjugate ATG8 from PE, resulting in autophagosome disassembly. Thus, inactivation of ATG4 following the initial cleavage of ATG8 is needed to ensure the structural integrity of the mature autophagosome. During cellular starvation and nutrient deprivation, there is an increased generation of mitochondrial derived hydrogen peroxide $\left(\mathrm{H}_{2} \mathrm{O}_{2}\right)$ through a PI3K/beclin-1 dependent pathway. ${ }^{3}$ 
This leads to oxidation and consequent inhibition of ATG4, ultimately promoting ATG8-PE conjugation and enhancing autophagy. ${ }^{3}$ Although ATG4 activity is regulated by the oxidative state of the local cellular environment, the question develops as to how ATG4 is initially activated to allow for ATG8 lipidation, but then becomes inhibited to allow the lipidation of ATG8 to remain. Interestingly, the priming step of ATG8 (cleavage at the C-terminus) is not affected during initial periods of nutrient deprivation, but rather it is the increased ROS generated over prolonged cellular starvation that leads to oxidation and subsequent inhibition of ATG4 (Fig. 2). ${ }^{3}$

ROS induce autophagy through a beclin-1 dependent pathway that is associated with autophagic induced cell-death. ${ }^{29}$ Beclin-1 is negatively regulated by its interaction with the anti-apoptotic protein $\mathrm{Bcl}-2$ under normal conditions. ${ }^{30}$ However, increased ROS activates the ubiquitin-proteosome system, which functions to degrade Bcl-2. ${ }^{31}$ This allows for beclin-1 activation subsequently resulting in autophagic cell death. ${ }^{29}$ Additionally, oxidized low density lipoproteins may enhance autophagy by upregulating beclin-1 gene expression. ${ }^{32}$ siRNA against beclin- 1 attenuates ROS-mediated ganglioside induced autophagic cell death. ${ }^{33}$

Increased autophagy reportedly occurs with mitochondrial damage and/or failure of the mitochondria to generate adequate ATP levels (i.e., during cell starvation), thus implicating a key role for mitochondria in autophagy. ${ }^{34,35}$ Inhibition of the mitochondrial electron transport chain (mETC) results in increased ROS production that is accompanied by cell death. ${ }^{36}$ Furthermore, inhibition of mETC complex I and complex II with rotenone and trifluoroacetone respectively caused ROS-mediated autophagicinduced cell death in transformed and cancer cell lines. ${ }^{37}$

Our laboratory among others has shown that aldosterone causes a generation in ROS in cultured adult rat ventricular myocytes. ${ }^{38}$ In vivo this leads to enhanced activity associated with cardiac remodeling including hypertrophy, increased matrix metalloproteinase activity, fibrosis, as well as apoptosis. ${ }^{39,40}$ Additionally, autophagic stimulation has been linked to pathologic conditions of cardiac remodeling in response to oxidative stress, endoplasmic reticulum stress, and changes in the ubiqutin-proteosomal system. ${ }^{41,42}$ Previous unpublished data from our laboratory suggests that pathological levels of ROS induce autophagic mediated cardiomyocyte death through an ERK-MAPK-dependent pathway. Further exploration into the exact mechanism of autophagic mediated cardiomyocyte death in response to severe oxidative stress is needed.

\section{Cellular Functions of Autophagy}

Autophagy serves many functions in response to various stimuli throughout a multitude of cell systems. Basal levels of autophagic degradation of longed lived cell components

\section{ROS-mediated induction of autophagy}

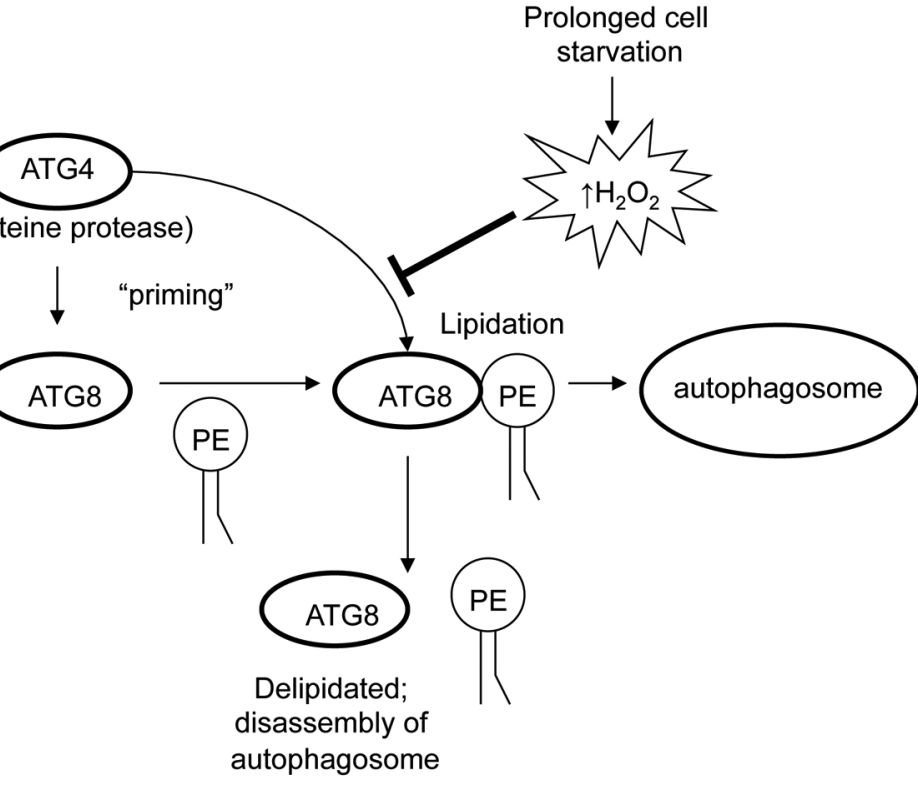

Figure 2. ROS-mediated induction of autophagy. ATG4 primes ATG8 homologues for conjugation with $\mathrm{PE}$, allowing for lipidated ATG8 incorporation into the autophagoof the mature autophagosome, thereby promoting autophagy. The initial priming step of ATG8 is unaffected during the early phases of nutrient deprivation and ROS eneration. However, over prolonged periods, the accumulating ROS generated will ead to oxidation and subsequent inhibition of ATG4.

(i.e., organelles, cytosolic proteins) occur in nearly all cell types as a means to maintain cellular homeostasis. ${ }^{4}$ A robust enhancement of autophagy has been observed in developing mouse embryos, suggesting that this process plays an important role in development and cell differentiation. ${ }^{3,4,43}$ Additionally, autophagy rapidly increases during periods of cellular starvation as a means to generate the necessary nutrients to sustain cell survival. ${ }^{44}$ However, excessive autophagy results in degradation of essential cell constituents, ultimately resulting in a process referred to as type-II cell death. ${ }^{45}$ Determinants of whether autophagy promotes cell survival or cell death depend upon the severity and degree of stress in the cellular environment. Autophagic degradation and removal of damaged oxidized proteins in response to oxidative stress is reportedly beneficial for the cell. ${ }^{46,47}$ Conversely, severe oxidative stress and increasing amounts of ROS may activate signaling pathways that lead to autophagic-induced cell death. ${ }^{48}$

\section{Oxidative-Stress Induced Autophagy in Response to Disease}

Many disease states are associated with elevated levels of ROS and increased oxidative stress and range from cardiovascularassociated disorders such as heart failure and diabetes, to neurodegenerative diseases, cystic fibrosis, rheumatoid arthritis and cancer. $^{49-55}$ Elevated ROS causing autophagy promotes either 
Table 1. Autophagy and ROS in disease states

\begin{tabular}{|c|c|c|c|}
\hline Disease & Cell/system & Function of autophagy & Reference \\
\hline Pathologic cardiac remodeling & Cardiac tissue & Oxidative stress-mediated autophagic cell death & 41,42 \\
\hline Heart failure & Cardiomyocytes & Pathologic levels of ROS-mediated autophagic cell death & unpublished \\
\hline $\begin{array}{l}\text { Myocardial infarction/ischemia } \\
\text { reperfusion (I/R) injury }\end{array}$ & Cardiomyocytes & $\begin{array}{l}\text { Xanthine oxidase mediated ROS generation exacerbates } \\
\text { autophagy and leads to death }\end{array}$ & $42,56-60$ \\
\hline $\begin{array}{l}\text { Renal ischemia reperfusion } \\
\text { injury }\end{array}$ & Renal tubule epithelial cells & $\begin{array}{l}\text { I/R-mediated ROS generation, increases autophagy and leads } \\
\text { to cell death }\end{array}$ & 74,75 \\
\hline $\begin{array}{l}\text { Stroke, neuronal ischemic } \\
\text { injury }\end{array}$ & Neuronal cells & $\begin{array}{l}\text { I/R-mediated ROS generation, increases autophagy and leads } \\
\text { to cell death }\end{array}$ & $76-78$ \\
\hline $\begin{array}{l}\text { Huntington disease, Alzheimer, } \\
\text { Parkinson }\end{array}$ & Neuronal cells & $\begin{array}{c}\text { ROS generation induces pro-survival autophagic removal of } \\
\text { harmful protein aggregates }\end{array}$ & $82-86$ \\
\hline Alzheimer & Neuronal cells & $\begin{array}{c}\text { Excessive ROS generation leading to mitochondrial } \\
\text { damage, increasing autophagic degradation of essential cell } \\
\text { constituents resulting in death }\end{array}$ & 97 \\
\hline Epilepsy & Neuronal cells & $\begin{array}{l}\text { ROS generation mediates cystatin C-induced autophagic } \\
\text { clearance of harmful aggregates (i.e., stefin B) }\end{array}$ & 87,88 \\
\hline Aging & Post-mitotic cells & $\begin{array}{l}\text { Impairment of lysosome/autophagosome fusion and loss of } \\
\text { autophagic function during aging leads to accumulation of } \\
\text { ROS and damaged cell material and cell death }\end{array}$ & $4,105,106,110$ \\
\hline Cancer/Tumor formation & $\begin{array}{l}\text { Prostate and colorectal cancer } \\
\text { cells }\end{array}$ & $\begin{array}{l}\text { Reduced autophagic activity accompanied by ROS } \\
\text { accumulation, somatic mutations and cancer pathogenesis }\end{array}$ & $63,121,122$ \\
\hline Cancer/Tumor survival & $\begin{array}{l}\text { Pre-exisiting tumors/multiple } \\
\text { myeloma cells, cervix carcinoma }\end{array}$ & $\begin{array}{l}\text { Cell starvation and ROS triggered autophagy promotes } \\
\text { tumor survival in nutrient deprived environments }\end{array}$ & $135,137-139$ \\
\hline
\end{tabular}

cell survival or cell death, the fate of which depends upon the severity of the stress occurring with a particular disease. The following sections discuss the autophagic response to increased ROS in various disease states and pathologic conditions. Refer to Table 1 for a summary of the role of autophagy in these diseases.

(1) Autophagy in vascular disease. Autophagic activity may be rapidly increased in response to vascular stress that occurs during ischemic episodes. Autophagy was first reported in cardiomyocytes by Sybers et al. in 1975, and occurs in response to acute coronary occlusion and myocardial infarction. ${ }^{42,56-60}$ Once coronary artery flow is reestablished, it can be classified as an ischemia/reperfusion (I/R) injury. During the initial period of ischemia, formation of the enzyme xanthine oxidase (XO) occurs and hypoxanthine and xanthine, both substrates for $\mathrm{XO}$, accumulate. ${ }^{61,62}$ Upon reperfusion, the reintroduction of molecular oxygen leads to $\mathrm{XO}$-mediated superoxide radical $\left(\mathrm{O}_{2}^{-}\right)$generation due to the presence of xanthine and hypoxanthine. ${ }^{57}$ During the initial period of hypoxia, a modest induction of autophagy occurs, and pharmacological inhibition of autophagy with 3-methyladenine (3-MA) decreased cardiomyocyte survival during ischemia, suggesting a cell survival role for autophagy during the initial ischemic insult. ${ }^{58,63}$ During this period, the resulting decrease in ATP generation results in the phosphorylation of AMP-activated protein kinase (AMPK), which leads to autophagosome formation through inhibition of mTOR. ${ }^{64,65}$ Ischemic insult also results in phosphorylation of heat shock protein (Hsp) 20 at serine residue 16, leading to cardioprotection by enhancing autophagy ${ }^{66}$ However, during reperfusion, ROS damages organelles, cytosolic proteins and causes lipid peroxidation in the mitochondria, all of which exacerbate autophagy. ${ }^{67}$ Additionally, antioxidants such as catalase and superoxide dismutase (SOD) are targeted by autophagosomes, thereby increasing the presence of ROS and creating a positive autophagic feedback loop. ${ }^{13}$ This ultimately leads to the induction of cell death and is thus detrimental to cell function. Furthermore, AMPK activity decreases during reperfusion, thus increasing autophagic death and beclin-1 upregulation..$^{58,64,68-70}$ Ischemic preconditioning of the myocardium may be an effective method against lethal ischemic injury, and studies have indicated that autophagy is involved in cardioprotection. Repetitive ischemia by coronary stenosis or coronary occlusion enhances autophagy and subsequent cardioprotection, compared to the classical I/R insult. ${ }^{71}$ Additionally, the antimicrobial agent sulfaphenazole, an inhibitor of cytochrome P4502C9, enhances autophagy in a PKC-dependent mechanism in the adult rat cardiomyocyte. ${ }^{72}$ This exhibited the same cardioprotective results against I/R injury similar to that of the preconditioned heart.

I/R injury induce ROS generation and autophagic-mediated cell death in the renal vasculature. Hypoxia induces autophagic cell death in human renal proximal tubular epithelial HK-2 cells, and autophagic inhibition prevented $\mathrm{H}_{2} \mathrm{O}_{2}$-induced cell death. ${ }^{73}$ Furthermore, overexpression of the anti-apoptotic protein $\mathrm{Bcl}-2$ in mice prevented autophagosome formation in I/R-injured renal tubular cells. ${ }^{74}$ Others reported that adenoviral administration of $\mathrm{Bcl}-\mathrm{xl}$, a member of the $\mathrm{Bcl}-2$ family, significantly reduced I/R-induced superoxide production and autophagy in the proximal and distal tubules of rat kidney. ${ }^{75}$ As in the myocardium, periods of intermittent reperfusion 
during prolonged ischemia protects against renal dysfunction as compared to classical I/R injury, and this involved an increase in antioxidant defense mechanisms and suppression of oxidative stress and autophagy. ${ }^{24}$

Enhanced autophagy activity is seen in ischemic events occurring in the cerebral vasculature. In the penumbra of rats exposed to cerebral ischemia there is increased beclin-1 and LC3 protein expression observed along with DNA damage in neuronal cells, suggesting cell death. ${ }^{76}$ Neonatal rats subjected to focal cerebral ischemia exhibited autophagosome specific LC3-II protein expression located in the periphery of neuronal lesions, indicating autophagic-mediated cell death. ${ }^{77}$ Post-ischemic treatment with the autophagic inhibitor 3-MA reduced the size of these lesions. Others showed that ATG7deficiant neonatal mice subjected to ischemic episodes were completely protected from neuronal death, suggesting ATG7 as a potential therapeutic target against neuronal cell death following ischemic brain injuries such as stroke. ${ }^{78}$ Repeated I/R in a rat spinal cord injury model resulted in enhanced immunoreactivity of LC3 and eventually neuronal death. ${ }^{79}$ Conversely, it has been suggested that activation of autophagy actually promotes cell survival in the initial stages of ischemic brain injury. ${ }^{80}$ Treatment with rapamycin, an autophagic inductor, increased beclin-1 expression, and lead to a reduction in cell death and neural injury in response to neonatal ischemic injury. Finally, ischemic-preconditioning lead to increased LC3-II expression in an in vitro PC12 cell model, and blockage of autophagy with 3-MA decreased cell viability, indicating that autophagy plays a neuroprotective role in ischemic preconditioning. ${ }^{81}$

(2) Role of autophagy in neurodegenerative disease. Debate continues as to whether autophagy directly contributes to neurodegenerative diseases or if it serves as a prosurvival response. Once again basal autophagy may lead to the clearance and degradation of potentially harmful protein aggregates that are associated with Huntington, Parkinson, and Alzheimer diseases, ${ }^{82-84}$ therefore being important in the protective maintenance of neural cells. ${ }^{85}$ For instance, in a dopamine D (2) receptor knockout mouse model of Parkinson's disease, increased oxidative stress and formation of alpha-synuclein aggregate is associated with increased autophagic activity. ${ }^{86}$ Confocal microscopy revealed colocalization of LC3 and stefin B aggregates, a protein linked with epileptic syndromes leading to neurodegeneration and increased oxidative stress. ${ }^{87}$ Cystatin $\mathrm{C}(\mathrm{Cys} \mathrm{C})$ is increased in the brain of animal models with neurodegenerative diseases and in human epileptic patients, and may have a neuroprotective role in response to oxidative stress. $\mathrm{Cys} C$ enhances autophagic clearance of aggregates via a mTOR dependent pathway. Conversely beclin-1 siRNA or 3-MA inhibits the neuroprotective role of CysC. ${ }^{88}$ ATG5 knockdown and suppression of basal autophagy caused protein aggregate accumulation in mouse neural cells and was accompanied by impaired motor function. Similarly, suppression of ATG7 in the central nervous system of mice was accompanied by impaired motor function, behavioral defects, protein inclusion body accumulation, neurodegeneration in both the cerebral and cerebellar cortices, and death. ${ }^{89}$ In both Drosophila and mouse models of polyglutamine diseases induction of autophagy with the use of rapamycin analogues prevents neurodegeneration. ${ }^{90}$ Furthermore, studies utilizing small molecular enhancers of rapamycin induced autophagic degradation of mutant Huntington protein aggregates and protected against neurotoxicity in Huntington disease cell and Drosophila models. ${ }^{11}$ Finally, overexpression of ATG8a gene in aged Drosophila brains promoted resistance to oxidative stress and prevented the build up of oxidized and ubiquitinated protein aggregates while extending lifespan. ${ }^{92}$ These findings suggest that pharmacologic modulators of autophagy may be applied as potential therapeutic interventions against neurodegenerative diseases.

In many cases, increased oxidative stress and ROS generation are observed in neurodegenerative disorders resulting in enhanced autophagic activity beyond basal levels. ${ }^{93}$ Under these conditions, autophagy is no longer considered a cell-survival mechanism, but promotes type-II programmed cell death. An increased number of autophagosomes are found in the brains of patients diagnosed with Alzheimer, Huntington and Parkinson diseases. ${ }^{86,90}$ Dopamine-toxicity inhibited mTOR, leading to an increase in LC3-II expression and cell loss in SH-SY5Y neuroblastoma cells. ${ }^{94,95}$ This was prevented with the antioxidant $\mathrm{N}$-acetylcysteine, suggesting that products of dopamine oxidation play a role in autophagic-induced neural cell degeneration. In Alzheimer disease, oxidative stress caused neuronal cell death by inducing autophagy of accumulated amyloid $\beta$-protein (Abeta) and subsequent permeabilization of the lysosomal membrane contributing to neuron death. ${ }^{96}$ Mitochondria damaged by oxidative stress in pyramidal neurons are subjected to autophagic degradation in Alzheimer disease (termed mitophagy), eventually leading to neurodegeneration. ${ }^{97}$ Finally, aberrant expression of protein phosphatase 2A (PP2A) is associated with the onset of a number of neural degenerative disorders. It was recently reported that neuroblastoma cells transfected with PP2A constructs have an increased susceptibility to oxidative stress mediated cell death, and inhibition of autophagy with siRNA against autophagic genes prevented this death. ${ }^{98}$

Another mechanism of oxidative stress induced autophagy in neural cells involves $\mathrm{Oxi}-\alpha$, a neuroprotective protein identified in dopamine neurons. ${ }^{99} \mathrm{Oxi}-\alpha$ is downregulated during oxidative stress, thus rendering neurons susceptible to oxidative stress induced death. Under normal conditions, Oxi- $\alpha$ activates mTOR, and thus suppresses autophagosome formation. However, increased levels of ROS downregulates Oxi- $\alpha$ and leads to decreased mTOR activity, thereby increasing autophagosome formation. Furthermore, inhibition of autophagy with 3-MA protected against neuronal death under oxidative stress, confirming the involvement of autophagy in cell-death in neurodegenerative diseases. ${ }^{100}$

(3) Autophagy and aging. Basal levels of oxidative stress as a result of aerobic metabolism over a lifespan will lead to alterations and damage to structures, eventually resulting in cell death. ${ }^{101}$ Lipofuscin and ceroid are related pigments that form in the presence of $\mathrm{H}_{2} \mathrm{O}_{2}$ and accumulate during aging in secondary lysosomes of post-mitotic cells. ${ }^{102,103}$ In both experimental and human models, there is an observed loss of autophagic 
function that occurs with aging and this is thought to be a major contributor to death of long-lived post-mitotic cells. ${ }^{104}$ As autophagic activity decreases during aging, it is unable to keep up with homeostatic maintenance of post-mitotic cells, resulting in an overload of ROS and damaged material, ultimately leading to cell death. ${ }^{105,106}$ Mitochondria obtained from ATG7deleted skeletal muscle cells displayed defective respiration and increased generation of ROS. ${ }^{107}$ Aged spleens from senescenceaccelerated prone mice revealed redox imbalance and age-related oxidative damage, as well as an upregulation of autophagic pathways believed to be a protective response to oxidative stress. ${ }^{108}$ It is also important to note that because autophagy initially plays a protective role against moderate oxidative stress, loss of autophagic function in aged cells is likely the reason why these cells have a lower tolerance to oxidative-induced injury. ${ }^{109}$

The mechanism responsible for age-associated autophagic impairment is unknown, but the inability of lipofuscin-loaded secondary lysosomes to fuse with autophagosomes to form the autophagolysosome may contribute. ${ }^{4}$ Suppression of autophagy with 3-MA in an aged-cell model lipofuscin-loaded human fibroblasts significantly accelerated cell death. ${ }^{101}$ In addition, aged liver cells exhibit an accumulation of autophagosomes whose contents are unable to undergo final lysosomal degradation due to this impairment of lysosome/autophagosome fusion. ${ }^{110}$ Others suggest that changes in hormone levels and glucose metabolism that occur during aging may also play a role in the impairment of autophagy. ${ }^{103,111}$ Nevertheless, studies on aging in Drosophila, nematodes and rodents have shown that activation of autophagy likely prevents aging, while autophagic inhibition promotes the aging process. ${ }^{15,112,113}$ This has led to investigators to explore potential methods of targeting autophagy to promote cell longevity. Spermidine, a naturally occurring polyamine that declines throughout a lifespan, inhibits oxidative stress and necrosis in aging yeast, and enhancing autophagy was essential for prevention of necrotic cell death. ${ }^{114}$ Because autophagy is strongly upregulated during periods of cell starvation and nutrient deprivation, it is believed that autophagy plays a key role in the anti-aging mechanism of caloric-restriction. ${ }^{15}$ Existing evidence supports this theory, as caloric-restriction has been shown to prevent agedependent changes in cell membrane and hormone signaling and occur with an increase in autophagy.

(4) Autophagy and cancer. The function of autophagy in cancer is debatable with data supporting both a survival role and cancer suppressive role. Reduced autophagic activity is observed in tumor development, suggesting that perhaps autophagy is primarily a mechanism for tumor suppression. ${ }^{116,117}$ Additionally, oxidative stress and ROS-generation have been implicated in the pathogenesis of cancer, with cancerous cells generating higher levels of ROS than healthy cells. ${ }^{118-120}$ ROS accumulation overtime has been known to induce somatic mutations, and oxidative stress is directly associated with the development of prostate and chronicinflammatory bowel disease-related colorectal cancer. ${ }^{63,121,122}$ The human oncosuppressive protein p53 promotes autophagy and reduces oxidative stress, suggesting that autophagy is exerting its tumor-suppressive actions in part by reducing levels of potentially mutagenic ROS. ${ }^{123}$ Another explanation for tumor-suppression by autophagy may be due to prolonged oxidative stress inducedautophagic cell death. $\mathrm{H}_{2} \mathrm{O}_{2}$ triggered autophagy-induced cell death in C6 glioma cells by BNIP3 inhibition of mTOR. ${ }^{124}$ ROS have been reported to induce autophagy in several cancer cell lines ${ }^{37,125-127}$ eventually resulting in cell death, while inhibition of autophagy with 3-MA or siRNA directed against ATGs inhibits this ROS-induced cell death. ${ }^{37}$ Allelic loss of beclin-1 is associated with human cancers that are susceptible to an accumulation of ROS and subsequent genomic damage and tumor growth. ${ }^{128}$

These findings give insight into the potential development of anti-cancer therapies that target autophagy for cancer prevention. For example, induction of oxidative stress by glucose oxidase or tert-butyl hydroperoxide induces autophagy and effectively suppresses tumor growth in a glioblastoma brain cancer model and HT-29 colon cancer cells respectively. ${ }^{37,129,130}$ Valproic acid, an anti-epileptic agent, was shown to also have tumor suppressing capabilities through an increase in ROS ERK1/2 dependent pathway that causes glioma cell death by autophagy. ${ }^{131}$ Interestingly, $\Delta^{9}$-tetrahydrocannabinol, the psychoactive compound found in marijuana, displays potential anti-tumor properties by inducing endoplasmic reticulum (ER)-stress and downstream inhibition of mTOR resulting in autophagic induced cell death. ${ }^{132}$ Autophagy induced by caloric restriction may prevent cancer, as caloric restriction has been reported to double the lifespan and delay tumor formation in mice. ${ }^{133,134}$ Pharmacologic agonists of autophagic pathways such as inhibitors of mTOR (i.e., rapamycin), and inhibitors targeting class I PI3K and 1,4,5-inositol triphosphate have been explored as potential chemotherapeutic agents. ${ }^{4,135,136}$ Additionally, chloroquine, an anti-malarial drug has been reported to prevent the development of lymphoma in mouse cancer models by activating autophagy. ${ }^{136}$

Contrary to its role in the prevention of tumor development, it is also argued that autophagy plays a survival role in existing tumors because of its ability to cope with the hypoxic and nutrient-deprived environments found within tumors. ${ }^{135,137}$ Thus, agents used to induce autophagy as a preventative measure for tumor development may not be desirable in existing tumors where autophagy plays a critical role for their survival. Both thapsigargin, an ER-stress inducing agent, and rapamycin increased autophagy in multiple myeloma cell lines, while autophagic inhibition by $3-\mathrm{MA}$ or beclin-1 siRNA resulted in cytotoxic effects and cell death. ${ }^{138}$ Evodiamine caused a timedependent generation of ROS and triggered autophagy in human cervix carcinoma HeLa cells, while pre-treatment with 3-MA decreased cell viability, again indicating that autophagy is having a survival role in these cancer cells. ${ }^{139}$ This complexity and dual roles of autophagy in cancer suggests that both agonists and inhibitors of autophagy should be considered as potential anti-cancer therapies.

\section{Targeting Autophagy as a Therapeutic Strategy Against Disease}

Since manipulation of autophagic pathways can influence cell survival, targeting these pathways is an attractive therapeutic strategy against disease. As described in the previous sections, 
Table 2. Drugs that influence autophagy in disease

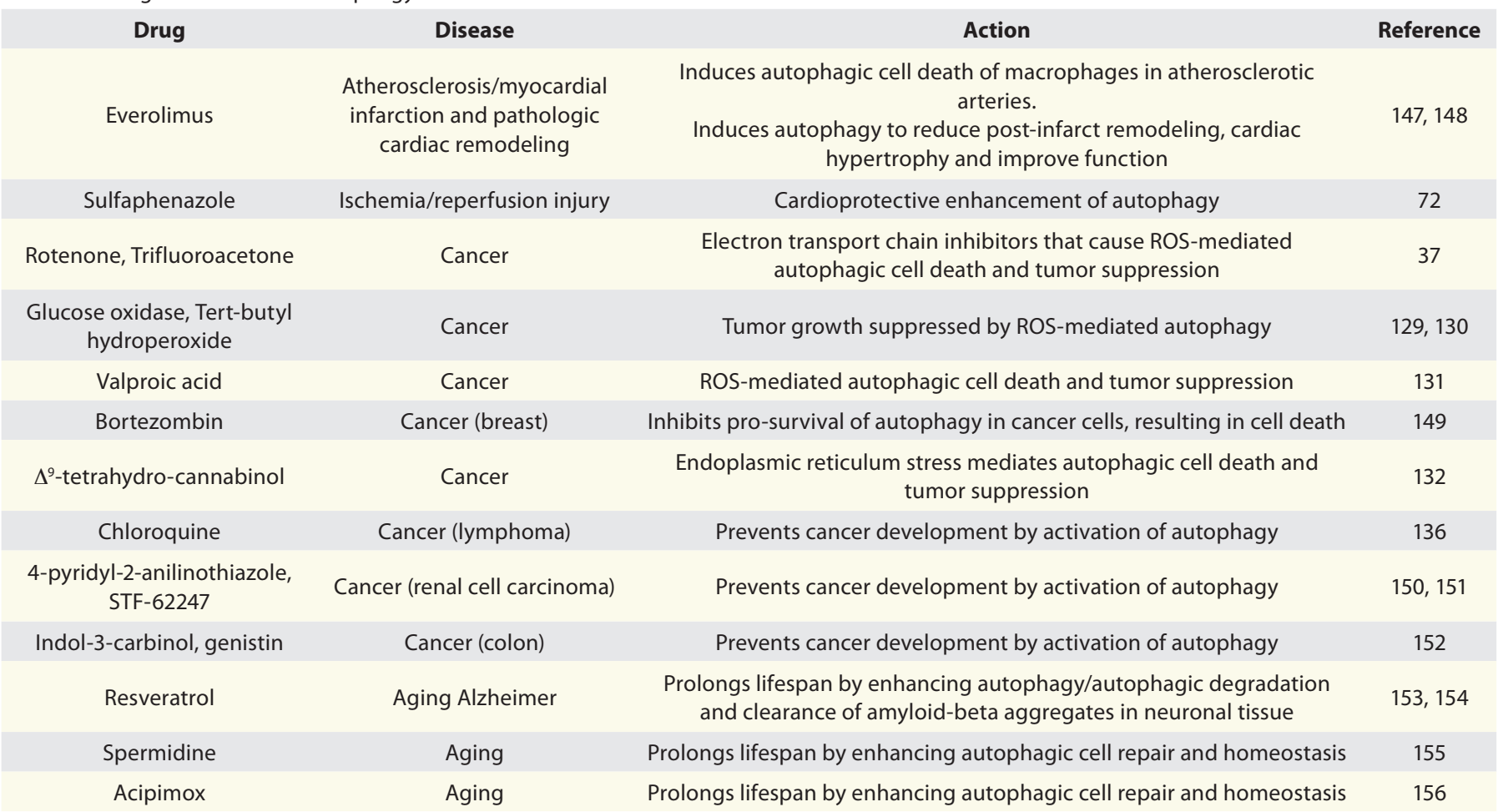

inhibition or activation of autophagy at the genetic level with siRNA against essential autophagic genes or overexpression/ constituent activation of these genes respectively, can affect cell viability. ${ }^{33,37,74,78,88,92,107,128,138,140-143}$ Common pharmacologic agents including 3-MA (an autophagic inhibitor) and rapamycin (autophagic activator) have been extensively utilized in laboratories to further characterize the role of autophagy in different cell systems. ${ }^{37,63,77,100,101,138,139,144-146}$ Additionally, the use of antioxidants such as NAC have also proved effective in preventing oxidative stress induced autophagy. ${ }^{95}$ In recent years, the development and exploration into novel pharmacologic therapies influencing autophagy has generated promising results against diseases. ${ }^{37,72,129-132,136,147-156}$ Refer to Table 2 for a summary of these drugs.

\section{References}

1. Fisher-Wellman K, Bell HK, Bloomer RJ. Oxidative stress and antioxidant defense mechanisms linked to exercise during cardiopulmonary and metabolic disorders. Oxid Med Cell Longev 2009; 2:56-60.

2. Groeger G, Quiney C, Cotter TG. Hydrogen peroxide as a cell-survival signaling molecule. Antioxidants \& Redox Signaling 2009; 11:2655-71.

3. Scherz-Shouval R, Shvets E, Fass E, Shorer H, Gil L, Elazar Z. Reactive oxygen species are essential for autophagy and specifically regulate the activity of Atg 4 . EMBO J 2007; 26:1749-60.

4. Levine B, Kroemer G. Autophagy in the pathogenesis of disease. Cell 2008; 132:27-42.

5. Wang J, Whiteman MW, Lian H, Wang G, Singh A, et al. A non-canonical MEK/ERK signaling pathway regulates autophagy via regulating Beclin 1 . J Biol Chem 2009; 284:21412-24.

6. Bejarano E, Cuervo AM. Chaperone-mediated autophagy. Proc Am Thorac Soc 2010; 7:29-39.
7. Kon M, Cuervo AM. Chaperone-mediated autophagy in health and disease. FEBS Lett 2010; 584:1399-404

8. Todde V, Veenhuis M, van der Klei IJ. Autophagy: principles and significance in health and disease. Biochim Biophys Acta 2009; 1792:3-13

9. Klionsky DJ, Ohsumi Y. Vacuolar import of proteins and organelles from the cytoplasm. Annu Rev Cell Dev Biol 1999; 15:1-32.

10. Takagi H, Matsui Y, Sadoshima J. The role of autophagy in mediating cell survival and death during ischemia and reperfusion in the heart. Antioxid Redox Signal 2007; 9:1373-81.

11. Nishida K, Yamaguchi O, Otsu K. Crosstalk between autophagy and apoptosis in heart disease. Circ Res 2008; 103:343-51.

12. Maiuri MC, Zalckvar E, Kimchi A, Kroemer G. Selfeating and self-killing: crosstalk between autophagy and apoptosis. Nat Rev Mol Cell Biol 2007; 8:741-52.

13. Scherz-Shouval R, Elazar Z. ROS, mitochondria and the regulation of autophagy. Trends Cell Biol 2007; $17: 422-7$.

\section{Summary}

The autophagic process is highly regulated and is stimulated by several factors and has a multiplicity of functions. While basal levels of autophagy constantly function to maintain cell homeostasis in virtually every cell type, autophagic activity can be rapidly enhanced in response to elevated levels of ROS. However, whether this is a pro-survival response or one that contributes ultimately to exploration into the complex and diverse ROS-mediated autophagy in different diseases, may reveal promising insights into pathogenic mechanisms, leading to novel therapeutic developments. Autophagy: Implications for Metabolism. Annu Rev Nutr 2007; 27:19-40.

15. Levine B, Klionsky DJ. Development by self-digestion: molecular mechanisms and biological functions of autophagy. Dev Cell 2004; 6:463-77.

16. Ohsumi Y. Molecular dissection of autophagy: two ubiquitin-like systems. Nat Rev Mol Cell Biol 2001, 2:211-6.

17. Mizushima N, Kuma A, Kobayashi Y, Yamamoto A Matsubae M, Takao T, et al. Mouse Apg16L, a novel WD-repeat protein, targets to the autophagic isolation membrane with the Apg12-Apg5 conjugate. J Cell Sci 2003; 116:1679-88

18. Mizushima N, Yamamoto A, Hatano M, Kobayashi Y, Kabeya Y, Suzuki K, et al. Dissection of Autophagosome Formation Using Apg5-Deficient Mouse Embryonic Stem Cells. J Cell Biol 2001; 152:657-68.

19. Mizushima N, Yoshimori T. How to interpret LC3 immunoblotting. Autophagy 2007; 3:542-5. 
20. Brady NR, Hamacher-Brady A, Yuan H, Gottlieb RA. The autophagic response to nutrient deprivation in the hl- 1 cardiac myocyte is modulated by Bcl-2 and sarco/ endoplasmic reticulum calcium stores. FEBS J 2007; 274:3184-97.

21. Yuan H, Perry CN, Huang C, Iwai-Kanai E, Carreira RS, Glembotski CC, et al. LPS-induced autophagy is mediated by oxidative signaling in cardiomyocytes and is associated with cytoprotection. Am J Physiol Heart Circ Physiol 2009; 296:470-9.

22. Jager S, Bucci C, Tanida I, Ueno T, Kominami E, Saftig $\mathrm{P}$, et al. Role for Rab7 in maturation of late autophagic vacuoles. J Cell Sci 2004; 117:4837-48.

23. Winchester BG. Lysosomal membrane proteins. Eur J Paediatr Neurol 2001; 5:11-9.

24. Wu HH, Hsiao TY, Chien CT, Lai MK. Ischemic conditioning by short periods of reperfusion attenuates renal ischemia/reperfusion induced apoptosis and autophagy in the rat. J Biomed Sci 2009; 16:19.

25. Azad MB, Chen Y, Gibson SB. Regulation of autophagy by reactive oxygen species (ROS): implications for cancer progression and treatment. Antioxid Redox Signal 2009; 11:777-90.

26. Moore MN, Viarengo A, Donkin P, Hawkins AJ Autophagic and lysosomal reactions to stress in the hepatopancreas of blue mussels. Aquat Toxicol 2007; 84:80-91.

27. Hemelaar J, Lelyveld VS, Kessler BM, Ploegh HL. A single protease, Apg4B, is specific for the autophagyrelated ubiquitin-like proteins GATE-16, MAP1LC3, GABARAP and Apg8L. J Biol Chem 2003; 278:51841-50.

28. Kabeya Y, Mizushima N, Ueno T, Yamamoto A, Kirisako T, Noda T, et al. LC3, a mammalian homologue of yeast Apg8p, is localized in autophagosome membranes after processing. EMBO J 2000; 19:5720-8.

29. De Meyer GR, Martinet W. Autophagy in the cardiovascular system. Biochim Biophys Acta 2009; 1793:1485-95.

30. Pattingre S, Tassa A, Qu X, Garuti R, Liang XH, Mizushima N, et al. Bcl-2 antiapoptotic proteins inhibit Beclin 1-dependent autophagy. Cell 2005; 122:927-39.

31. Breitschopf K, Haendeler J, Malchow P, Zeiher AM, Dimmeler S. Posttranslational modification of Bcl-2 facilitates its proteasome-dependent degradation: molecular characterization of the involved signaling pathway. Mol Cell Biol 2000; 20:1886-96.

32. Zabirnyk O, Liu W, Khalil S, Sharma A, Phang JM. Oxidized low-density lipoproteins upregulate proline oxidase to initiate ROS-dependent autophagy. Carcinogenesis 2010; 31:446-54.

33. Hwang J, Lee S, Lee JT, Kwon TK, Kim DR, et al. Gangliosides induce autophagic cell death in astrocytes. Br J Pharmacol 2010.

34. Gozuacik D, Kimchi A. Autophagy as a cell death and tumor suppressor mechanism. Oncogene 2004; 23:2891-906.

35. Levine B, Yuan J. Autophagy in cell death: an innocent convict? J Clin Invest 2005; 115:2679-88.

36. Li N, Ragheb K, Lawler G, Sturgis J, Rajwa B, Melendez JA, et al. Mitochondrial complex I inhibitor rotenone induces apoptosis through enhancing mitochondrial reactive oxygen species production. J Biol Chem 2003; 278:8516-25.

37. Chen Y, Millan-Ward E, Kong J, Israels SJ, Gibson SB. Oxidative stress induces autophagic cell death independent of apoptosis in transformed and cancer cells. Cell Death Differ 2008; 15:171-82.

38. Rude MK, Duhaney TA, Kuster GM, Judge S, Heo J, Colucci WS, et al. Aldosterone stimulates matrix metalloproteinases and reactive oxygen species in adult rat ventricular cardiomyocytes. Hypertension 2005; 46:555-61.

39. Lebrasseur NK, Duhaney TA, De Silva DS, Cui L, Ip PC, Joseph L, et al. Effects of fenofibrate on cardiac remodeling in aldosterone-induced hypertension. Hypertension 2007; 50:489-96.
40. De Silva DS, Wilson RM, Hutchinson C, Ip PC, Garcia AG, Lancel S, et al. Fenofibrate inhibits aldosterone-induced apoptosis in adult rat ventricular myocytes via stress-activated kinase-dependent mechanisms. Am J Physiol Heart Circ Physiol 2009; 296:1983-93.

41. Cao DJ, Gillette TG, Hill JA. Cardiomyocyte autophagy: remodeling, repairing and reconstructing the heart. Curr Hypertens Rep 2009; 11:406-11.

42. Nishida K, Kyoi S, Yamaguchi O, Sadoshima J, Otsu $\mathrm{K}$. The role of autophagy in the heart. Cell Death Differ 2009; 16:31-8.

43. Tsukamoto S, Kuma A, Murakami M, Kishi C, Yamamoto A, Mizushima N. Autophagy is essential for preimplantation development of mouse embryos. Science 2008; 321:117-20.

44. Lum JJ, Bauer DE, Kong M, Harris MH, Li C, Lindsten T, et al. Growth factor regulation of autophagy and cell survival in the absence of apoptosis. Cell 2005; 120:237-48.

45. Gozuacik D, Kimchi A. Autophagy and cell death; in Gerald PS, (ed): Current Topics in Developmental Biology. Academic Press 2007; 217-45.

46. Lemasters JJ, Nieminen AL, Qian T, Trost LC, Elmore SP, Nishimura Y, et al. The mitochondrial permeability transition in cell death: a common mechanism in necrosis, apoptosis and autophagy. Biochim Biophys Acta 1998; 1366:177-96.

47. Xiong Y, Contento AL, Nguyen PQ, Bassham DC. Degradation of oxidized proteins by autophagy during oxidative stress in Arabidopsis. Plant Physiol 2007; 143:291-9.

48. Kirkland RA, Adibhatla RM, Hatcher JF, Franklin JL. Loss of cardiolipin and mitochondria during programmed neuronal death: evidence of a role for lipid peroxidation and autophagy. Neuroscience 2002; 115:587-602.

49. Trachtenberg BH, Hare JM. Biomarkers of oxidative stress in heart failure. Heart Fail Clin 2009; 5:561-77.

50. Francia P, Cosentino F, Schiavoni M, Huang Y, Perna E, Camici GG, et al. p66(Shc) protein, oxidative stress and cardiovascular complications of diabetes: the missing link. J Mol Med 2009; 87:885-91.

51. Ando K, Fujita T. Metabolic syndrome and oxidative stress. Free Radic Biol Med 2009; 47:213-8.

52. Liu CY, Lee CF, Wei YH. Role of reactive oxygen species-elicited apoptosis in the pathophysiology of mitochondrial and neurodegenerative diseases associated with mitochondrial DNA mutations. J Formos Med Assoc 2009; 108:599-611.

53. Mirshafiey A, Mohsenzadegan M. The role of reactive oxygen species in immunopathogenesis of rheumatoid arthritis. Iran J Allergy Asthma Immunol 2008; 7:195202

54. Pongnimitprasert N, El-Benna J, Foglietti MJ, Gougerot-Pocidalo MA, Bernard M, Braut-Boucher F. Potential role of the "NADPH oxidases" (NOX/ DUOX) family in cystic fibrosis. Ann Biol Clin 2008; 66:621-9.

55. Auten RL, Davis JM. Oxygen toxicity and reactive oxygen species: the devil is in the details. Pediatr Res 2009; 66:121-7.

56. Goldhaber JI, Weiss JN. Oxygen free radicals and cardiac reperfusion abnormalities. Hypertension 1992; 20:118-27.

57. Misra MK, Sarwat M, Bhakuni P, Tuteja R, Tuteja N. Oxidative stress and ischemic myocardial syndromes. Med Sci Monit 2009; 15:209-19.

58. Matsui Y, Takagi H, Qu X, Abdellatif M, Sakoda $\mathrm{H}$, Asano T, et al. Distinct roles of autophagy in the heart during ischemia and reperfusion: roles of AMPactivated protein kinase and beclin 1 in mediating autophagy. Circ Res 2007; 100:914-22.

59. Hamacher-Brady A, Brady NR, Gottlieb RA Enhancing macroautophagy protects against ischemia/ reperfusion injury in cardiac myocytes. J Biol Chem 2006; 281:29776-87.
60. Sybers HD, Ingwall J, DeLuca M. Autophagy in cardiac myocytes. Recent Adv Stud Cardiac Struct Metab 1976; 12:453-63.

61. Chambers DE, Parks DA, Patterson G, Roy R, McCord JM, Yoshida S, et al. Xanthine oxidase as a source of free radical damage in myocardial ischemia. J Mol Cell Cardiol 1985; 17:145-52.

62. DeWall RA, Vasko KA, Stanley EL, Kezdi P. Responses of the ischemic myocardium to allopurinol. Am Heart J 1971; 82:362-70.

63. Seril DN, Liao J, Yang GY, Yang CS. Oxidative stress and ulcerative colitis-associated carcinogenesis: studies in humans and animal models. Carcinogenesis 2003; 24:353-62.

64. Matsui Y, Kyoi S, Takagi H, Hsu CP, Hariharan N, Ago T, et al. Molecular mechanisms and physiological significance of autophagy during myocardial ischemia and reperfusion. Autophagy 2008; 4:409-15.

65. Horman S, Beauloye C, Vertommen D, Vanoverschelde JL, Hue L, Rider MH. Myocardial ischemia and increased heart work modulate the phosphorylation state of eukaryotic elongation factor-2. J Biol Chem 2003; 278:41970-6

66. Qian J, Ren X, Wang X, Zhang P, Jones WK, Molkentin JD, et al. Blockade of Hsp20 phosphorylation exacerbates cardiac ischemia/reperfusion injury by suppressed autophagy and increased cell death. Circ Res 2009; 105:1223-31.

67. Juhaszova M, Zorov DB, Kim SH, Pepe S, Fu Q Fishbein KW, et al. Glycogen synthase kinase- $3^{+}$mediates convergence of protection signaling to inhibit the mitochondrial permeability transition pore. J Clin Invest 2004; 113:1535-49.

68. Qu X, Yu J, Bhagat G, Furuya N, Hibshoosh H, Troxe A, et al. Promotion of tumorigenesis by heterozygous disruption of the beclin 1 autophagy gene. J Clin Invest 2003; 112:1809-20.

69. Yue Z, Jin S, Yang C, Levine AJ, Heintz N. Beclin 1, an autophagy gene essential for early embryonic development, is a haploinsufficient tumor suppressor. Proc Nat Acad Sci USA 2003; 100:15077-82.

70. Zhu H, Tannous P, Johnstone JL, Kong Y, Shelton JM, Richardson JA, et al. Cardiac autophagy is a maladaptive response to hemodynamic stress. J Clin Invest 2007; 117:1782-93

71. Yan L, Sadoshima J, Vatner DE, Vatner SF. Autophagy in ischemic preconditioning and hibernating myocardium. Autophagy 2009; 5:709-12.

72. Huang C, Liu W, Perry CN, Yitzhaki S, Lee Y, Yuan H, et al. Autophagy and protein kinase $\mathrm{C}$ are required for cardioprotection by sulfaphenazole. Am J Physiol Heart Circ Physiol 2010; 298:570-9.

73. Suzuki C, Isaka Y, Takabatake Y, Tanaka H, Koike M, Shibata M, et al. Participation of autophagy in renal ischemia/reperfusion injury. Biochem Biophys Res Commun 2008; 368:100-6.

74. Isaka Y, Suzuki C, Abe T, Okumi M, Ichimaru N, Imamura $\mathrm{R}$, et al. $\mathrm{Bcl}-2$ protects tubular epithelial cells from ischemia/reperfusion injury by dual mechanisms. Transplant Proc 2009; 41:52-4.

75. Chien CT, Shyue SK, Lai MK. Bcl- $x_{L}$ augmentation potentially reduces ischemia/reperfusion induced proximal and distal tubular apoptosis and autophagy. Transplantation 2007; 84:1183-90.

76. Rami A. Upregulation of beclin 1 in the ischemic penumbra. Autophagy 2008; 4:227-9.

77. Puyal J, Vaslin A, Mottier V, Clarke PG. Postischemic treatment of neonatal cerebral ischemia should target autophagy. Ann Neurol 2009; 66:378-89.

78. Koike M, Shibata M, Tadakoshi M, Gotoh K, Komatsu $\mathrm{M}$, Waguri $\mathrm{S}$, et al. Inhibition of autophagy prevents hippocampal pyramidal neuron death after hypoxicischemic injury. Am J Pathol 2008; 172:454-69.

79. Baba H, Sakurai M, Abe K, Tominaga R. Autophagymediated stress response in motor neuron after transient ischemia in rabbits. J Vasc Surg 2009; 50:381-7. 
80. Carloni S, Buonocore G, Balduini W. Protective role of autophagy in neonatal hypoxia-ischemia induced brain injury. Neurobiol Dis 2008; 32:329-39.

81. Park HK, Chu K, Jung KH, Lee ST, Bahn JJ, Kim M, et al. Autophagy is involved in the ischemic preconditioning. Neurosci Lett 2009; 451:16-9.

82. Ravikumar B, Duden R, Rubinsztein DC. Aggregateprone proteins with polyglutamine and polyalanine expansions are degraded by autophagy. Hum Mol Genet 2002; 11:1107-17.

83. Webb JL, Ravikumar B, Atkins J, Skepper JN, Rubinsztein DC. Alpha-synuclein is degraded by both autophagy and the proteasome. J Biol Chem 2003; 278:25009-13.

84. Lee JA, Gao FB. Regulation of Abeta pathology by beclin 1: a protective role for autophagy? J Clin Invest 2008; 118:2015-8.

85. Martinet W, Agostinis P, Vanhoecke B, Dewaele M, De Meyer GR. Autophagy in disease: a double-edged sword with therapeutic potential. Clin Sci 2009; 116:697-712.

86. Tinsley RB, Bye CR, Parish CL, Tziotis-Vais A, George $S$, Culvenor JG, et al. Dopamine D2 receptor knockout mice develop features of Parkinson disease. Ann Neurol 2009; 66:472-84.

87. Ceru S, Layfield R, Zavasnik-Bergant T, Repnik U, Kopitar-Jerala N, Turk V, et al. Intracellular aggregation of human stefin B: confocal and electron microscopy study. Biol Cell 2010; 102:319-34

88. Tizon B, Sahoo S, Yu H, Gauthier S, Kumar AR, Mohan P, et al. Induction of autophagy by cystatin C: a mechanism that protects murine primary cortical neurons and neuronal cell lines. PLoS One 2010; 5:9819.

89. Komatsu M, Waguri S, Chiba T, Murata S, Iwata Ji, Tanida I, et al. Loss of autophagy in the central nervous system causes neurodegeneration in mice. Nature 2006; 441:880-4.

90. Rubinsztein DC, Gestwicki JE, Murphy LO, Klionsky DJ. Potential therapeutic applications of autophagy. Nat Rev Drug Discov 2007; 6:304-12.

91. Sarkar S, Perlstein EO, Imarisio S, Pineau S, Cordenier A, Maglathlin RL, et al. Small molecules enhance autophagy and reduce toxicity in Huntington's disease models. Nat Chem Biol 2007; 3:331-8.

92. Simonsen A, Cumming RC, Brech A, Isakson P, Schubert DR, Finley KD. Promoting basal levels of autophagy in the nervous system enhances longevity and oxidant resistance in adult Drosophila. Autophagy 2008; 4:176-84

93. Martinez A, Portero-Otin M, Pamplona R, Ferrer I. Protein targets of oxidative damage in human neurodegenerative diseases with abnormal protein aggregates. Brain Pathol 2010; 20:281-9.

94. Sulzer D, Zecca L. Intraneuronal dopamine-quinone synthesis: a review. Neurotox Res 2000; 1:181-95.

95. Gimenez-Xavier P, Francisco R, Santidrian AF, Gil J, Ambrosio S. Effects of dopamine on LC3-II activation as a marker of autophagy in a neuroblastoma cell model. Neurotoxicology 2009; 30:658-65.

96. Zheng L, Kagedal K, Dehvari N, Benedikz E, Cowburn $\mathrm{R}$, Marcusson J, et al. Oxidative stress induces macroautophagy of amyloid beta-protein and ensuing apoptosis. Free Radic Biol Med 2009; 46:422-9.

97. Moreira PI, Siedlak SL, Wang X, Santos MS, Oliveira $\mathrm{CR}$, Tabaton $\mathrm{M}$, et al. Increased autophagic degradation of mitochondria in Alzheimer disease. Autophagy 2007; 3:614-5.

98. Cheng WT, Guo ZX, Lin CA, Lin MY, Tung LC, Fang $\mathrm{K}$. Oxidative stress promotes autophagic cell death in human neuroblastoma cells with ectopic transfer of mitochondrial PPP2R2B (Bbeta2). BMC Cell Biol 2009; 10:91.

99. Yoo MS, Kawamata H, Kim DJ, Chun HS, Son JH. Experimental strategy to identify genes susceptible to oxidative stress in nigral dopaminergic neurons. Neurochem Res 2004; 29:1223-34.
100. Choi KC, Kim SH, Ha JY, Kim ST, Son JH. A novel mTOR activating protein protects dopamine neurons against oxidative stress by repressing autophagy related cell death. J Neurochem 2010; 112:366-76.

101. Stroikin Y, Johansson U, Asplund S, Ollinger K. Increased resistance of lipofuscin-loaded prematurely senescent fibroblasts to starvation-induced programmed cell death. Biogerontology 2007; 8:43-53.

102. Kiffin R, Bandyopadhyay U, Cuervo AM. Oxidative stress and autophagy. Antioxid Redox Signal 2006; 8:152-62.

103. Terman A, Brunk UT. Aging as a catabolic malfunction. Int J Biochem Cell Biol 2004; 36:2365-75.

104. Martinez-Vicente M, Cuervo AM. Autophagy and neurodegeneration: when the cleaning crew goes on strike. Lancet Neurol 2007; 6:352-61.

105. Terman A, Gustafsson B, Brunk UT. Mitochondria damage and intralysosomal degradation in cellular aging. Mol Aspects Med 2006; 27:471-82.

106. Terman A, Brunk UT. Myocyte aging and mitochondrial turnover. Exp Gerontol 2004; 39:701-5.

107. Wu JJ, Quijano C, Chen E, Liu H, Cao L, Fergusson $\mathrm{MM}$, et al. Mitochondrial dysfunction and oxidative stress mediate the physiological impairment induced by the disruption of autophagy. Aging 2009; 1:425-37.

108. Caballero B, Vega-Naredo I, Sierra V, Gonzalo-Calvo D, Medrano-Campillo P, Guerrero JM, et al. Autophagy upregulation and loss of NFkappaB in oxidative stressrelated immunodeficient SAMP8 mice. Mech Ageing Dev 2009; 130:722-30.

109. Vittorini S, Paradiso C, Donati A, Cavallini G, Masin $\mathrm{M}$, Gori Z, et al. The age-related accumulation of protein carbonyl in rat liver correlates with the age-related decline in liver proteolytic activities. J Gerontol A Biol Sci Med Sci 1999; 54:318-23.

110. Terman A. The effect of age on formation and elimination of autophagic vacuoles in mouse hepatocytes. Gerontology 1995; 41:319-26.

111. Del RA, Vittorini S, Cavallini G, Donati A, Gori Z, Masini M, et al. Ageing-related changes in the in vivo function of rat liver macroautophagy and proteolysis. Exp Gerontol 2003; 38:519-27.

112. Simonsen A, Cumming RC, Finley KD. Linking lysosomal trafficking defects with changes in aging and stress response in Drosophila. Autophagy 2007; 3:499501.

113. Vellai T, Takacs-Vellai K, Zhang Y, Kovacs AL, Orosz L, Muller F. Genetics: influence of TOR kinase on lifespan in C. elegans. Nature 2003; 426:620.

114. Eisenberg T, Knauer H, Schauer A, Buttner S, Ruckenstuhl C, Carmona-Gutierrez D, et al. Induction of autophagy by spermidine promotes longevity. Nat Cell Biol 2009; 11:1305-14.

115. Cavallini G, Donati A, Gori Z, Bergamini E. Towards an understanding of the anti-aging mechanism of caloric restriction. Curr Aging Sci 2008; 1:4-9.

116. Kisen GO, Tessitore L, Costelli P, Gordon PB, Schwarze $\mathrm{PE}$, Baccino FM, et al. Reduced autophagic activity in primary rat hepatocellular carcinoma and ascites hepatoma cells. Carcinogenesis 1993; 14:2501-5.

117. Levine B. Unraveling the role of autophagy in cancer. Autophagy 2006; 2:65-6.

118. Pelicano H, Carney D, Huang P. ROS stress in cancer cells and therapeutic implications. Drug Resist Updat 2004; 7:97-110.

119. Schumacker PT. Reactive oxygen species in cancer cells: live by the sword, die by the sword. Cancer Cell 2006; 10:175-6.

120. Waris G, Ahsan H. Reactive oxygen species: role in the development of cancer and various chronic conditions. J Carcinog 2006; 5:14

121. Khandrika L, Kumar B, Koul S, Maroni P, Koul HK. Oxidative stress in prostate cancer. Cancer Lett 2009; 282:125-36.

122. Itzkowitz SH, Yio X. Inflammation and cancer IV Colorectal cancer in inflammatory bowel disease: the role of inflammation. Am J Physiol Gastrointest Liver Physiol 2004; 287:7-17.
123. Galluzzi L, Morselli E, Kepp O, Maiuri MC, Kroemer G. Defective autophagy control by the $\mathrm{p} 53$ rheostat in cancer. Cell Cycle 2010; 9:250-5.

124. Byun YJ, Kim SK, Kim YM, Chae GT, Jeong SW, Lee SB. Hydrogen peroxide induces autophagic cell death in C6 glioma cells via BNIP3-mediated suppression of the mTOR pathway. Neurosci Lett 2009; 461:131-5.

125. Djavaheri-Mergny M, Amelotti M, Mathieu J, Bauvy $\mathrm{C}$, et al. NFKB activation represses tumor necrosis factor- $\alpha$-induced autophagy. J Biol Chem 2006; 281:30373-82.

126. Guo Wj, Ye Ss, Cao N, Huang J, Gao J, Chen Qy. ROS-mediated autophagy was involved in cancer cell death induced by novel copper(II) complex. Exp Toxicol Pathol 2009; In press.

127. Yacoub A, Hamed HA, Allegood J, Mitchell C, Spiegel $S$, Lesniak MS, et al. PERK-dependent regulation of ceramide synthase 6 and thioredoxin play a key role in mda-7/IL-24-induced killing of pPrimary human glioblastoma multiforme cells. Cancer Res 2010; 70:1120-9.

128. Mathew R, Karp CM, Beaudoin B, Vuong N, Chen G, Chen HY, et al. Autophagy suppresses tumorigenesis through elimination of p62. Cell 2009; 137:1062-75.

129. Garcia-Escudero V, Gargini R. Autophagy induction as an efficient strategy to eradicate tumors. Autophagy 2008; 4:923-5.

130. Chen F, Wang CC, Kim E, Harrison LE. Hyperthermia in combination with oxidative stress induces autophagic cell death in HT-29 colon cancer cells. Cell Biol Int $2008 ; 32: 715-23$

131. Fu J, Shao CJ, Chen FR, Ng HK, Chen ZP. Autophagy induced by valproic acid is associated with oxidative stress in glioma cell lines. Neuro Oncol 2010; 12:328-40.

132. Salazar M, Carracedo A, Salanueva IJ, HernandezTiedra S, Lorente M, Egia A, et al. Cannabinoid action induces autophagy-mediated cell death through stimulation of ER stress in human glioma cells. J Clin Invest 2009; 119:1359-72.

133. Bartke A, Wright JC, Mattison JA, Ingram DK, Miller RA, Roth GS. Extending the lifespan of long-lived mice. Nature 2001; 414:412.

134. Berrigan D, Perkins SN, Haines DC, Hursting SD. Adult-onset calorie restriction and fasting delay spontaneous tumorigenesis in p53-deficient mice. Carcinogenesis 2002; 23:817-22.

135. Steeves MA, Dorsey FC, Cleveland JL. Targeting the autophagy pathway for cancer chemoprevention. Curr Opin Cell Biol 2010.

136. Maclean KH, Dorsey FC, Cleveland JL, Kastan MB Targeting lysosomal degradation induces p53-dependent cell death and prevents cancer in mouse models of lymphomagenesis. J Clin Invest 2008; 118:79-88.

137. Degenhardt K, Mathew R, Beaudoin B, Bray K, Anderson D, Chen G, et al. Autophagy promotes tumor cell survival and restricts necrosis, inflammation and tumorigenesis. Cancer Cell 2006; 10:51-64.

138. Hoang B, Benavides A, Shi Y, Frost P, Lichtenstein A. Effect of autophagy on multiple myeloma cell viability. Mol Cancer Ther 2009; 8:1974-84.

139. Yang J, Wu LJ, Tashino S, Onodera S, Ikejima T. Reactive oxygen species and nitric oxide regulate mitochondria-dependent apoptosis and autophagy in evodiamine-treated human cervix carcinoma HeLa cells. Free Radic Res 2008; 42:492-504.

140. Hara T, Nakamura K, Matsui M, Yamamoto A, Nakahara Y, Suzuki-Migishima R, et al. Suppression of basal autophagy in neural cells causes neurodegenerative disease in mice. Nature 2006; 441:885-9.

141. Juhasz G, Neufeld TP. Drosophila Atg7: required for stress resistance, longevity and neuronal homeostasis, but not for metamorphosis. Autophagy 2008; 4:357-8.

142. Schoenlein PV, Periyasamy-Thandavan S, Samaddar JS, Jackson WH, Barrett JT. Autophagy facilitates the progression of ERalpha-positive breast cancer cells to antiestrogen resistance. Autophagy 2009; 5:400-3. 
143. Vazquez-Martin A, Oliveras-Ferraros C, Menendez JA. Autophagy facilitates the development of breast cancer resistance to the anti-HER2 monoclonal antibody trastuzumab. PLoS One 2009; 4:6251.

144. Carloni S, Buonocore G, Balduini W. Protective role of autophagy in neonatal hypoxia-ischemia induced brain injury. Neurobiol Dis 2008; 32:329-39.

145. Park HK, Chu K, Jung KH, Lee ST, Bahn JJ, Kim M, et al. Autophagy is involved in the ischemic preconditioning. Neurosci Lett 2009; 451:16-9.

146. Balduini W, Carloni S, Buonocore G. Autophagy in hypoxia-ischemia induced brain injury: evidence and speculations. Autophagy 2009; 5:221-3.

147. Martinet W, Verheye S, De Meyer GR. Everolimusinduced mTOR inhibition selectively depletes macrophages in atherosclerotic plaques by autophagy. Autophagy 2007; 3:241-4.

148. Buss SJ, Muenz S, Riffel JH, Malekar P, Hagenmueller M, Weiss CS, et al. Beneficial effects of Mammalian target of rapamycin inhibition on left ventricular remodeling after myocardial infarction. J Am Coll Cardiol 2009; 54:2435-46
149. Periyasamy-Thandavan S, Jackson WH, Samaddar JS, Erickson B, Barrett JR, Raney L, et al. Bortezomib blocks the catabolic process of autophagy via a cathepsin-dependent mechanism, affects endoplasmic reticulum stress and induces caspase-dependent cell death in antiestrogen-sensitive and resistant $\mathrm{ER}^{+}$breast cancer cells. Autophagy 2010; 6:19-35.

150. Hay MP, Turcotte S, Flanagan JU, Bonnet M, Chan DA, Sutphin PD, et al. 4-Pyridylanilinothiazoles that selectively target von Hippel-Lindau deficient renal cell carcinoma cells by inducing autophagic cell death. J Med Chem 2010; 53:787-97.

151. Turcotte S, Chan DA, Sutphin PD, Hay MP, Denny WA, Giaccia AJ. A molecule targeting VHL-deficient renal cell carcinoma that induces autophagy. Cancer Cell 2008; 14:90-102.

152. Nakamura Y, Yogosawa S, Izutani $Y$, Watanabe $\mathrm{H}$ Otsuji E, Sakai T. A combination of indol-3-carbinol and genistein synergistically induces apoptosis in human colon cancer HT-29 cells by inhibiting Ak phosphorylation and progression of autophagy. Mol Cancer 2009; 8:100
153. Morselli E, Galluzzi L, Kepp O, Criollo A, Maiuri MC Tavernarakis N, et al. Autophagy mediates pharmacological lifespan extension by spermidine and resveratrol. Aging 2009; 1:961-70.

154. Vingtdeux V, Giliberto L, Zhao H, Chandakkar P, Wu Q, Simon JE, et al. AMP-activated protein kinase signaling activation by resveratrol modulates amyloid-beta peptide metabolism. J Biol Chem 2010; 285:9100-13.

155. Madeo F, Eisenberg T, Buttner S, Ruckenstuhl C, Kroemer G. Spermidine: a novel autophagy inducer and longevity elixir. Autophagy 2010; 6:160-2.

156. Donati A, Cavallini G, Carresi C, Gori Z, Parentini I, Bergamini E. Anti-aging effects of anti-lipolytic drugs. Exp Gerontol 2004; 39:1061-7. 


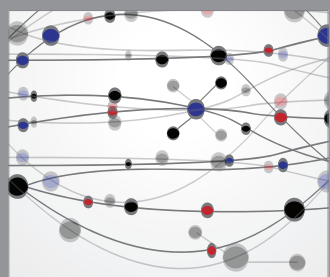

The Scientific World Journal
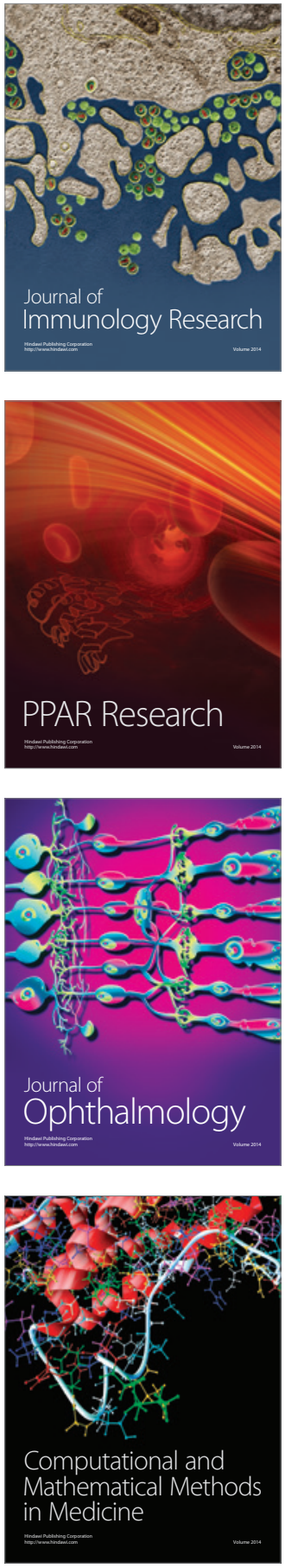

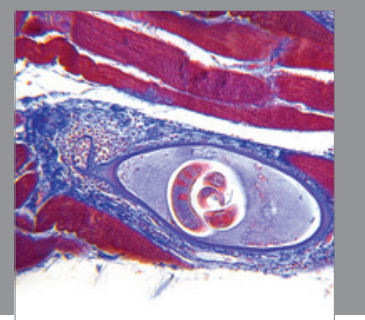

Gastroenterology

Research and Practice
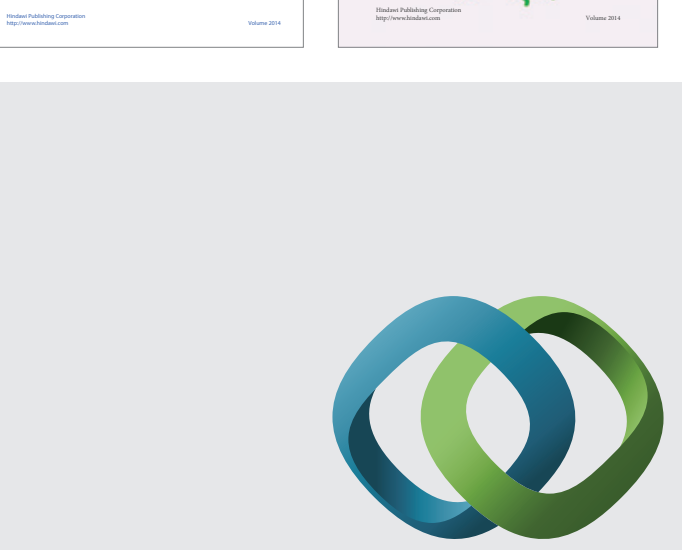

\section{Hindawi}

Submit your manuscripts at

http://www.hindawi.com
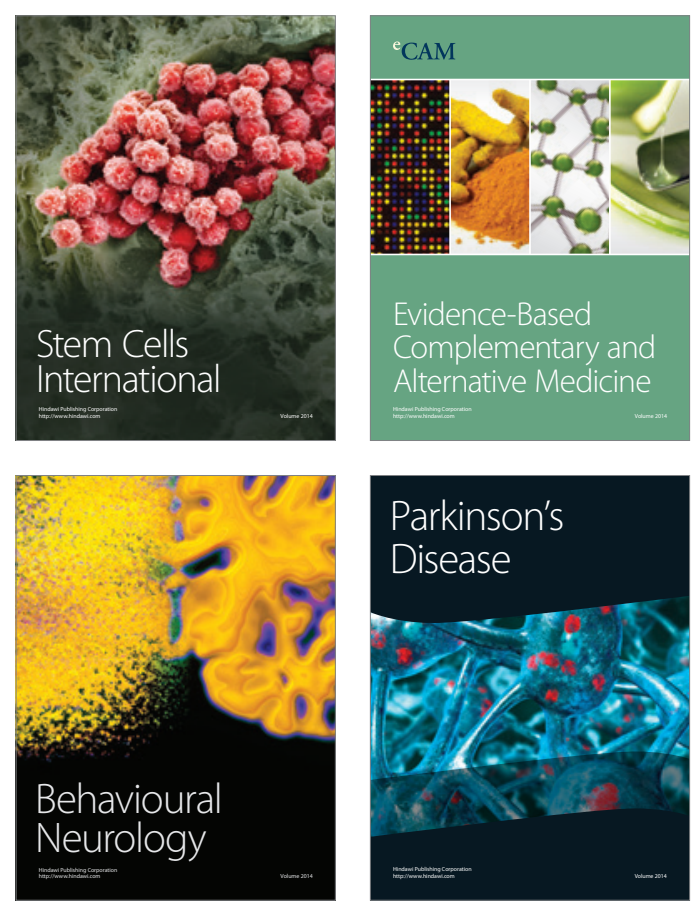

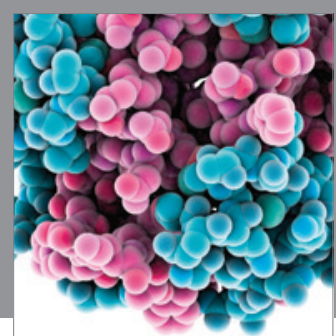

Journal of
Diabetes Research

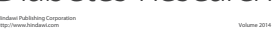

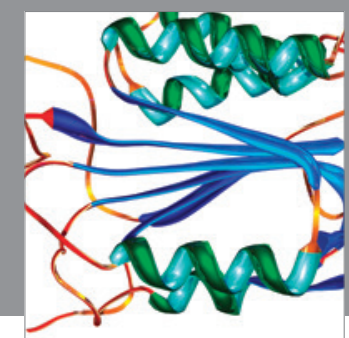

Disease Markers
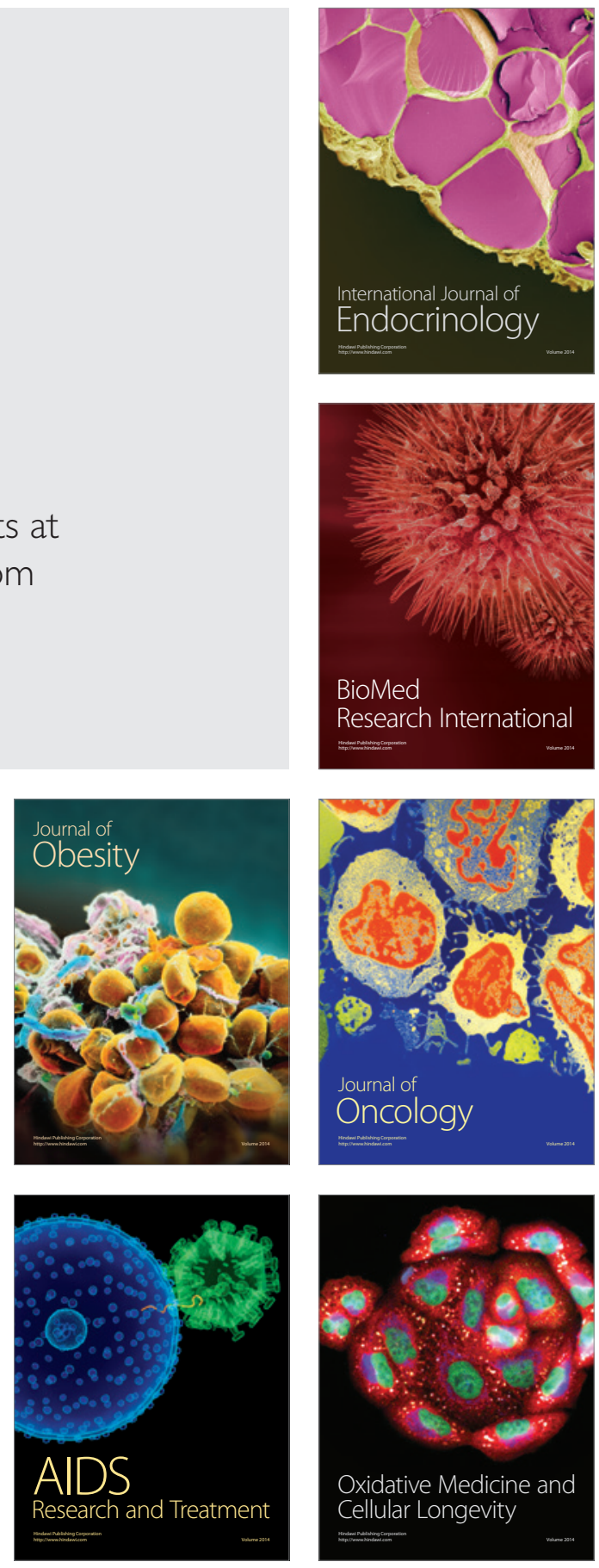